\title{
Carlos Fuentes, Balzac
}

\section{Marco Stupazzoni}

\section{(2) OpenEdition}

\section{Journals}

\section{Edizione digitale}

URL: https://journals.openedition.org/studifrancesi/9601

DOI: 10.4000/studifrancesi.9601

ISSN: 2421-5856

\section{Editore}

Rosenberg \& Sellier

\section{Edizione cartacea}

Data di pubblicazione: 1 décembre 2007

Paginazione: 680

ISSN: 0039-2944

\section{Notizia bibliografica digitale}

Marco Stupazzoni, «Carlos Fuentes, Balzac», Studi Francesi [Online], 153 (LI | III) | 2007, online dal 30 novembre 2015, consultato il 20 novembre 2021. URL: http://journals.openedition.org/studifrancesi/ 9601 ; DOI: https://doi.org/10.4000/studifrancesi.9601

Questo documento è stato generato automaticamente il 20 novembre 2021.

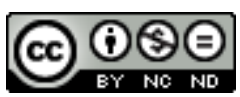

Studi Francesi è distribuita con Licenza Creative Commons Attribuzione - Non commerciale - Non opere derivate 4.0 Internazionale. 


\title{
Carlos Fuentes, Balzac
}

\author{
Marco Stupazzoni
}

\section{NOTIZIA}

CARLOS FUENTES, Balzac, in In questo io credo, traduzione di Eleonora MOGAVERo, Milano, Il Saggiatore, «Nuovi Saggi», 2005, pp. 26-30.

1 Credo in Balzac, dichiara Carlos Fuentes all'inizio di questo breve capitolo dedicato allo scrittore francese; e nel ripercorrere le pagine di tre fra i più inquietanti romanzi visionari della Comédie humaine: La Peau de chagrin, Séraphita e Louis Lambert, egli trova più di una occasione per celebrare il genio di Balzac e per gettare nuova luce su alcune tematiche proprie della sua scrittura narrativa. Il genio balzachiano, scrive l'autore, «si manifesta nella tensione fra il tempo e lo spazio dei suoi romanzi» (p. 27): come nel caso de La Peau de chagrin e di Séraphîta, vita e morte, possesso ed esproprio delle cose, erotismo e desiderio si fondono in un'unica ma poliedrica dimensione mitica (il mito di Tantalo) che «illumina l'iconografia fantastique» (p. 28) del romanziere. Attraverso il romanzo di Balzac, è legittimo dunque chiedersi se la letteratura può sconfiggere la morte? Balzac, conclude Fuentes, «ha visto che il possesso offre la vita e alla fine la toglie. Ma ha potuto farlo soltanto nella misura in cui ha saputo identificare il suo romanzo in quanto testo, in quanto struttura verbale che conferisce permanenza e contenuto a tutto quello che rifiuta di avere l'una o l'altro, ovvero alla fugacità della vita e al possesso delle cose» (p. 30). 